\title{
Jsem Phuoc, ale řríkej mi Lucky
}

\author{
Lenka Bednárová \\ Katedra antropologie, FF ZČU, Sedláčkova 15, 30100 Plzeň \\ Do redakce doručeno 26. dubna 2016; k publikaci přijato 5. ř́jna 2016
}

\section{I’M PHUOC BUT CALL ME LUCKY}

ABSTRACT This paper is focused on using names and nicknames among young Vietnamese, their perception of this phenomenon and transformation of name during growing up. Project is focused on reacting on situational and institutional changes of name in specific society. Data was founded on qualitative research, concretely interviews and participant observation among young Vietnamese (20-30 years old) in the Czech Republic and also in Vietnam.

KEY WORDS Vietnamese; name; nickname; qualitative research; migration

ABSTRAKT Studie se zaměřuje na užívání vlastních jmen a přezdívek u mladých Vietnamců, jejich vnímání tohoto fenoménu a proměnu preference používání oficiálního vietnamského jména a přezdívky během dospívání. Zároveň práce reaguje na situační a institucionální proměnu jména v konkrétním prostředí. Data byla získána formou kvalitativního výzkumu, zejména hloubkovými rozhovory a zúčastněným pozorováním mezi mladými Vietnamci ve věku 20-30 let v Čechách i ve Vietnamu.

KLÍČOVÁ SLOVA Vietnamci; jména; přezdívky; kvalitativní výzkum; migrace

V roce 1595 napsal William Shakespeare v jednom ze svých nejslavnějších dramat větu „Co jest to jméno? To, co růží zvem, pod jiným jménem sladce vonělo by zrovna tak. " ${ }^{\text {" }} \mathrm{V}$ té chvíli nemohl patrně ani tušit, jak zajímavým materiálem se stanou jména a pojmenování pro sociální vědce. Navíc $\mathrm{v}$ současné době by mnozí $\mathrm{z}$ nich $\mathrm{s}$ touto jeho částečně esencialistickou myšlenkou jistě polemizovali, jelikož jména nejenže odkazují $\mathrm{k}$ představám dané společnosti o světě a člověku, ale zároveň mnohdy vytvářejí sociální vztahy a identitu jedince (vom Bruck - Bodenhorn 2006, 2; 25-27). „Zajímá nás pochopení důležitosti jména, jakožto klíčového prvku, v němž lidé vytvářejí sami sebe a kolektivní myšlení“ (vom Bruck - Bodenhorn 2006, 5). Z konstruktivistického hlediska by tak právě naše jméno mohlo být labelem, který nám dává pocit sounáležitosti s určitou skupinou. To vše je

1 Odkaz na W. Shakespeara v divadelní hře „Romeo a Julie“ (do českého jazyka přeložil Josef Václav Sládek, překlad online publikován 2011). ještě podpořeno skutečností, že máme umožněno jméno modifikovat i během života, a to oficiální i neoficiální cestou. Jak často je ovšem jméno využíváno nejen jako symbol a identifikační známka, ale také jako osobní taktika jednání v určitém kulturním prostředí?

Předkládaná studie je věnována problematice pojmenování a přezdívek na prríkladu mladých Vietnamců v České republice, částečně také ve Vietnamu. Srovnáním těchto dvou prostředí budou ukázány strategie, které můžeme nalézt $\mathrm{v}$ rámci užívání jmen a přezdívek v obou zmíněných částech světa. Zároveň bude poukázáno na to, jak jsou jednotlivá jména a přezdívky užívány napříč pomyslnými hranicemi jednotlivých skupin.

Data, která jsou v textu používána, byla shromážděna v rámci kvalitativního výzkumu. Ten se odehrával v České republice i ve Vietnamu a jeho účastníky se stali studenti univerzit $\mathrm{v}$ obou zemích ve věku dvaceti až třiceti let. Jméno v práci není uchopováno pouze jako symbolická a identifikační kategorie, ale jako procesuální označení, které zjednodušuje je- 
dinci fungování v různorodých společnostech. Samotné užívání jména/přezdívky ho zařazuje do určité skupiny, ve které se právě chce nacházet.

\section{VIETNAMŠTÍ „CIZINCI“}

Stejně jako v České republice jsou Vietnamci považováni za minoritní skupiny mnoha dalších zemí ${ }^{2}$ a to i přesto, že výraznější migrační toky $z$ Vietnamu můžeme sledovat až ve 20 . století, do té doby se jednalo o posuny obyvatelstva $\mathrm{z}$ velké části jen $\mathrm{v}$ rámci vnitřního území země, migraci za prací či sňatkem a rodinou. Vietnam jako jedna ze součástí Indočíny patřil společně s Kambodžou a Laosem pod područí francouzské koloniální správy. Nezávislost na Francii vyhlásil v roce 1946. Za původce této změny je označován komunistický vůdce Ho Chi Minh - Vietnamci familiérně označovaný „strýček Ho“. Francie nezávislost Vietnamu uznává až v roce 1954 na základě konference v Ženevě (Buss 1958). Následně ovšem dochází k rozkolu mezi severním a jižním Vietnamem - mohli bychom říci mezi pro a protikomunistickými částmi země, což zároveň vede $\mathrm{k}$ jedněm $\mathrm{z}$ prvních masových migračních vln $\mathrm{z}$ této oblasti Asie. Vše je podpořeno vietnamsko-americkou válkou v letech 1955-1975, která je stále silně znatelná a připomínána v myšlenkách zdejší populace.

Do zemí západního bloku odcházeli lidé, kteří mnohdy nesouhlasili s komunistickým režimem, jednalo se zejména o obyvatele jižních částí Vietnamu. $\mathrm{K}$ východnímu bloku se zase obraceli zejména lidé ze severu, $\mathrm{z}$ nichž první $\mathrm{z}$ nich přicházeli za studiem a za prací, obojí bylo hromadně organizováno na základě bilaterálních smluv (Brouček 2003, 11-20, Kocourek 2007). Od doby prvních migrantů se v zemi začal objevovat mýtus západních zemí jako místa blahobytu a práce, což není vzhledem k realitě chudého Vietnamu nic překvapivého. Navíc $\mathrm{v}$ posledních letech se rozmohl i turistický boom směřující do Vietnamu a stal se pro místní jakýmsi utvrzujícím důkazem „Západního bohatstvi““ (Pechová 2007, 19; Freidingerová 2014, 54-57). Angličtina se nadneseně řečeno stává lingvou frankou Asie (Kirkpatrick 2010). Od základní školy se vietnamské děti učí anglickému jazyku a jedním z preferovaných povolání je jmenován např́klad i učitel angličtiny či průvodce pro cestovní kanceláře. Jak bude ukázáno právě tento styk se „západními cizinci“"vytváří prostředí pro tvorbu přezdívek a modifikaci oficiálních vietnamských jmen.

I přes rozsáhlé množství etnických skupin, které můžeme na území Vietnamu nalézt (Dang a kol. 2000), se migrační vlny $\mathrm{v}$ rámci bilaterálních smluv mezi Vietnamskou socialistickou republikou a Československou socialistickou republikou týkaly výhradně Vietů. V našem prostředí nalézáme řadu prací orientovaných na proměnu vnímání Vietnamců v ČR, identitu, etnické a nacionální cítění a začlenění do české společnosti (Brouček 2003a, 2003b; Černík 2006; Kocourek 2006;

2 Ze zemí bývalého východního bloku se jedná zejména o naše sousedy - Polsko či Německo. Naopak migranti v západním bloku směřovali do USA, Švédska či Anglie (Freidingerová 2014, 58-106).
Martínková 2008, 2010). Tyto práce reflektují vývoj integrace vietnamské menšiny od počátků migrace v polovině 20. století na základě smluvních vztahů a bilaterálních smluv mezi Československou republikou a Vietnamem, až po následné strategie jedinců po roce 1989 a současnou situaci v české společnosti, ovlivněnou například třetí vlnou migrace projevující se výrazným podnikatelským podtextem (Brouček 2003b). Zkoumají první a druhou generaci Vietnamců žijících v ČR a následně také novou vlnu migrace z Vietnamu, u níž je za hlavní cíl považováno zlepšení ekonomické situace jedince (Martínková 2010, 8-13 a 38-39). V současné době hovoříme u vietnamských migrantů v Čechách kromě původních příchozích i o první a půlté a druhé generaci (Freidingerová 2014, 28-29 a 70).

Vzhledem $\mathrm{k}$ tomu, že se $\mathrm{v}$ př́padě vietnamských migrantů jedná o migraci takzvaně rodinnou (Cooke 2008) zachovávají si Vietnamci transnacionální vazby s př́ibuznými ve Vietnamu i ve světě a rodiny se tak nachází „zde i tam“ (Evergeti - Ryan 2011, 356). Tímto způsobem se jim podařilo zachovat nejen hodnoty, tradice, oslavy svátků, ale také jazyk. Udržování komunikace s rodinou ve Vietnamu může být označeno za jeden $\mathrm{z}$ důvodů, proč i mladí Vietnamci v období dospívání obnovují své znalosti vietnamštiny, i přestože primárně užívají češtinu. Právě vietnamská jména a vietnamštinu můžeme chápat jako pojítko v užívání jmen. Ve zmiňovaném výzkumu mají všichni informanti ve Vietnamu i v Čechách svá oficiální vietnamská jména, ale $\mathrm{z}$ různých důvodů využívají přezdívky a pseudonymy, aby mohli lépe fungovat v kooperaci s „cizinci“. Vedle individuálních přezdívek, jimž je věnována tato práce, můžeme u Vietnamců identifikovat i pojmenování některých konkrétních skupin. Ti, kteří žijí v zahraničí, jsou označování Việt Kiếu, jedná se o termín pocházející s čínštiny, který odkazuje na někoho, kdo přebývá v cizí zemi. Vietnamci v ČR navíc sami sebe označují termínem Việt Xù, což pochází z foneticky odvozené koncovky českého slova „Vietnamcü“ (Freidingerová 2014, 27-31).

\section{METODOLOGIE}

V obou zemích byl výzkum veden formou kvalitativního empirického šetření (Hammersley - Atkinson 1997; Berg 2001), je ovšem nutné zmínit, že s respondenty $\mathrm{v}$ českém prostředí mohl být výzkum díky menší jazykové bariéře a většímu časovému prostoru mnohem detailnější. Ve Vietnamu byl realizován zejména prostřednictvím neformálních rozhovorů a zúčastněného pozorování (Spradley 1980; Bernard 2006, 342-386), zatímco v České republice bylo toto šetření navíc doplněno o hloubkové polostrukturované rozhovory (Bernard 1995, 208-236; Bernard 2006, 256-258).

Informanti byli v obou zemích získáváni metodou snow-ballu (Toušek 2012, 58-59), a to bezprostředně po vstupu do terénu. Zúčastněné pozorování v jižním Vietnamu probíhalo mezi studenty univerzity $\mathrm{z}$ rozličných oborů, od technických po humanitní, ve věku 20-30 let. $Z$ rozsáhlé sítě informantů tak byla vytvořena užší skupina deseti jedinců, se kterými byly vedeny face to face rozhovory. $\mathrm{V}$ rámci pozorování bylo důle- 
žité zaregistrovat zejména reakce informantů při seznamování s cizinci ve chvíli, kdy jim sdělovali svá vlastní jména, jejich výslovnost a také rychlost $\mathrm{s}$ jakou přistoupili na modifikaci jména či užití přezdívky.

Př́klad - modifikace jména překladem, rozhovor s Luckym (26 let):

Phuoc se ani nesnažil mi sdělit vlastní jméno a rovnou s úsměvem a sebevědomím prohlásil:

"Já jsem Lucky."

"Lucky?"

„Tak joo.. jsem Phuoc, ale to je pro tebe asi těžký, tak to necháme jako Lucky³, v překladu moje vlastní jméno je něco jako štěstí, takže tak..."

$\mathrm{Na}$ základě poznatků $\mathrm{z}$ vietnamského prostředí byly ověřovány podobné mechanismy a př́stupy také u Vietnamců v Čechách. Polostrukturované rozhovory byly vedeny s 12 informanty ( 6 ženami, 6 muži) ve věku 20-30 let. Specifikem této věkové skupiny Vietnamců v Čechách je, že se povětšinou jedná o zástupce takzvané první a půlté a druhé generace Vietnamců v České republice označované médii, akademiky i Vietnamci samotnými za takzvané banánové děti (Černík $2006,184)$. Jedná se o potomky původních migrantů, kteří velice často považují Českou republiky za svůj domov, plánují zde svůj budoucí život, mají české přátele a češtinu ovládají Z velké části jako rodný jazyk (Sataryová 2014).

Rozhovor se skládal z obecné části o informantovi, vysvětlení jeho vlastního jména, získání neoficiálního českého „jména“ neboli přezdívky a užívání obojího. Opět uvedu pro představu čtenáře konkrétní příklad:

„Ve školce neumèli moje jméno vyslovit, tak mi vymysleli jméno Tomáš a tak nějak se to ujalo, jestli je to podobné mému vietnamskému jménu? Popravdè nemyslím si." (Tomáš, 22 let)

Data získaná výzkumem můžeme rozdělit následovně: Data ze zúčastněného pozorování ve Vietnamu; relační data, pocházející z neformálních i polostrukturovaných rozhovorů v obou zemích, která vypovídají o situacích a vztazích, v nichž jedinec užívá přezdívky a různé formy svého jména a atribuční data - kulturní data získaná díky odpovědím informantů na konkrétní otázky, vypovídající o daných skutečnostech v souvislosti s užíváním přezdívek. ${ }^{5}$

Na základě získaných dat probíhala tematická analýza, jejíž pomocí byly vyhledávány a označovány jednotlivé fenomény, které se v rámci užívání jmen a přezdívek vyskytují: (1) Vlastní jména (2) Příjmení (3) Přezdívky (4) Taktika užívání, aj.. Následně je interpretace zaměřená na obecné zacházení

3 Lucky - anglický výraz pro „stěstí/mít štěsti“, poznámka autorky.

4 Metaforické označení, dle kterého jsou jedinci z vnějšku „žlutí, ale uvnitř jsou „bílí“ - vypadají jako Vietnamci, ale díky výchově na českých školách a v českém kolektivu se v mnoha ohledech chovají jako Češi.

5 Rozdělení dat na data atribuční a relační: Toušek, 2012, s. 32-37. se jménem, př́jmením a přezdívkou. Za oficiální jméno je považováno vietnamské jméno, kterým se jedinec prokazuje a identifikuje v oficiálních situacích, kdy musí prokazovat svou totožnost. Přezdívky samotné rozděluji na česká neoficiální jména a modifikace jména jeho přeložením do jiného jazyka, krácení nebo změnou výslovnosti a podobně. Tato neoficiální jména bychom také mohli označit jako pseudonymy. Text zároveň reflektuje strategie, které jsou s užíáním jména a přezdívek prímo spojené.

\section{ZACHÁZENÍ S OSLOVENÍM}

Předtím než budou představeny konkrétní specifika jmen, př́ijmení a přezdívek věnujme pozornost dvěma oblastem, které mohou mít vliv na jména, respektive jejich vyslovování a identifikování - mateřskému jazyku mluvčích (vietnamštině) a genderu aktéra. Jedním $\mathrm{z}$ charakterových znaků vietnamské společnosti je silná hierarchie, která se odráží i v samotné vietnamštině. Při oslovení se rozlišuje věk oslovovaného, postavení v rodině i gender.

Příklad:

Oslovení starší sestry/ženy jménem Anh - chi Anh

Oslovení staršího muže jménem Thin - anh Thin

Oslovení mladší osoby jménem Linh - em Linh

„Když to jsou kamarádi tak česky Janina, a když jsou mladší tak vietnamsky - protože by mě měli oslovit i 'chi' jakože sestra“" (Jana, 24 let)

Vietnamština náleží mezi austroasijské jazyky a celkově se odhaduje, že je na světě zhruba 70 miliónů jejích mluvčích. Zápis vietnamštiny je uváděn $\mathrm{v}$ latince, a to pravděpodobně zásluhou jezuitských mnichů. ${ }^{6}$ Za její určité specifikum můžeme ovšem pokládat složitou výslovnost, ta se skládá ze šesti různých tónů (Nguyễn a kol. 2013). Právě to může nezasvěcenému mluvčímu způsobit obtíže při vyslovování nejen jednotlivých slov, nýbrž i samotných jmen.

Př́klad konkrétního jména Binh: výslovnost jména Binh se na první pohled nemusí jevit nijak zvlášt náročně. Pokud ovšem nevíte, že bịnh vysloveno ve sníženém tónu může také znamenat „nemocný“ a oslovovaného nijak nepotěšíte, pokud jméno vyslovíte špatně.

Klasický zápis evropských a celkově západních jmen se skládá $s$ křestního jména a př́imení, přičemž bývá většinou na první pohled patrné, o které z nich se jedná. Oproti tomu u zápisu vietnamských jmen se př́jmení užívá jako první, následuje druhé př́padně i třetí křestní jméno a první křestní jméno.

\section{Př́iklad zápisu jména:}

Mužské jméno: Lê Minh Quốc Anh/ Nguyễn Dược Thịn (Anh a Thịn spíše mužská jména)

6 Zásluhy za zápis vietnamštiny do latinky i popsání gramatiky tohoto jazyka jsou připisovány jezuitskému mnichovi Alexandru de Rhodesovi (Alves 2009). 
Ženské jméno: Lê Thị Mỹ Tuyết / Nguyễn Thị Thu Hường (Thị ve jméně odkazuje na ženu)

U některých jmen můžeme v zápisu rozeznat i gender jedince, například Anh nebo Thịn často odkazuje k muži a Thị uprostřed jména spíše k ženě. Zde je nutné upozornit, že se jedná o ideální prrípady jmen a ne vždy může být toto posouzení sto procentní. Některá jména jsou navíc stejná pro muže i pro ženy, př́kladem může být jméno Linh. Tyto náležitosti jména znesnadňují neznalým jedincům správné zacházení s oficiálním vietnamskými jmény, což $\mathrm{v}$ mnohých př́padech může vézt $k$ potřebě jméno modifikovat, jak bude ukázáno níže.

\section{JMÉNA A PŘÍJMENÍ}

Svou pozornost si jména zasloužila nejen jako značka identity a znázornění sociálních/rodinných vztahů (Finch 2008), nýbrž také jako klasifikační systém odkazující na sociální organizaci a ideologii společnosti (Geertz - Geertz 1964), včetně označení opravňujícího jedince $\mathrm{k}$ vystoupení nebo zařazení se do klasifikace dané skupiny (Levi-Strauss 1996, 222; 231). Mohou tímto zpo̊sobem být „užívána jako 'databáze' používaná jedinci jako 'př́stupové heslo' pro přestup skrze různé geografické, etnické a náboženské dimenze, přes systém hodnot a základní etnické stereotypy“ (Bankova 2008, 130). Tímto způsobem chápou někteří kolegové $\mathrm{z}$ řad sociálních vědců např́klad etnická jména (Aceto 2012) nebo naopak zvolení takového oficiálního jména, které je typické pro majoritní společnost (Gerhard - Silke 2009).

Co se týká pojmenovávání samotného, jsou Vietnamci často svázáni s tradicí a pověrčivostí. Stejně jako v mnoha př́ípadech po celém světě mohou jména nést mystický či symbolický význam, být tabuizována či dokonce zcela zakázána dle jejich vhodnosti (Goodenough 1965, 271; Barnes 1967, 112) a je jim tak přikládána mnohdy moc nad jedincem a jeho osudem.

„My jsme tři sourozenci. U mě to jméno vybírala mamka, takže mě pojmenovala po tehdejši známý vietnamský zpěvačce a ten druhej brácha, toho pojmenoval dèda a znamená to něco ve smyslu jakože stoupání a úspěch. Ty jména většinou nemají prímo preklad, prímo se nedají přeložit do vietnamštiny, spousta výrazů je převzatá s čínštiny, takže třeba to bráchovo jméno je taky taková staročinština. Třetí brácha se v překladu jmenuje Tančicí drak" (Jo 25 let)

Častým jevem je přejímání jmen a jejich významu z čínštiny. Vietnam je značně ovlivňován čínskou kulturou $v$ historii $\mathrm{i}$ $\mathrm{v}$ současnosti. $\mathrm{V}$ rámci mladé generace zároveň i korejskou zejména kulturní scénou. Zároveň to zapř́íčiňuje, že jména jsou často špatně přeložitelná do vietnamštiny, natož do dalších jazyků jako je např́klad angličtina či čeština. Přesto se dají povětšinou významově $\mathrm{k}$ něčemu připodobnit (viz prríklad se jménem Phuoc - štěstí). Jména mohou být ovšem vybrána i na základě obdivu $\mathrm{k}$ nějaké osobě, hrdinovi či členovi rodiny a nemusí být vždy spojeno s určitým symbolem nebo překladem.

„Měla jsem mít jméno, co má ted’ moje mladší ségra, ale když jsem se měla narodit, tak byly hrozný závěje, takže než jsem dojela do nemocnice, tak jsem se skoro narodila $v$ autě - tak jsem dostalo to jméno znázorňující světlo a sníh. Ségra je 'Perla' a bráchovi vybral jméno děda - podle vysněného jména pro svého druhého prípadného syna." (Hana, 23 let)

$\mathrm{V}$ některých rodinách informantů se objevila i s tabuizace jména předků, které nesmí být znovu použito u dalších generací - jednat by se ovšem mělo o první křestní jméno, jelikož prostřední jména se $\mathrm{v}$ rodině často opakují, např́iklad sestry mohou mít stejné prostřední jméno, ale ani jedna $\mathrm{z}$ nich by se neměla jmenovat po babičce či matce.

"Ještě nevím, zda to platí i z matky na dceru, já bych chtěla, aby moje dcera měla stejné prostřední jméno, ale nevím, zda se to smí, musím to ještě zjistit. A kdyby jo, tak se holt podř́dím." (Kim, 20 let)

Do pojmenovávání může významně zasáhnout u potomků širší rodina, a to i v př́padě, kdy se nalézá na jiném kontinentu. Často tak např́klad nestaršímu synovi/vnukovi vybere jméno dědeček, v čemž se odráží hierarchie rodiny a postavení nejstaršího syna. Ten je označován za nejcennějšího a očekávaného člena rodiny, který má být pokračovatelem tradic, na něhož by měla přejít odpovědnost za rodinu, rodinný oltář předků. Včetně předpokladu, že by se měl i jako první ze své generace $\mathrm{v}$ rodině oženit. To ovšem již $\mathrm{v}$ dnešní době zejména $\mathrm{v}$ rodinách migrantů nebývá vždy naplňováno, ani přímo vyžadováno.

Nejčastějším př́ímením ve Vietnamu je Nguyễn, které je zastoupeno zhruba $38,4 \%$ vietnamské populace, následováno je př́ijmeními Trần (12,1\%), Lê (9,5\%) či Phạm (7\%) (Lê 2005). Své prvenství si př́ijmení Nguyễn nese i mezi vietnamskými migranty v českém prostředí. Rozšířenost tohoto př́jmení se přičítá císařské rodině sídlící až do poloviny 20. století v Hue (Nguyên 1985). Nguyễn bylo jménem rodu této dynastie, která ho měla zároveň udělovat jedincům jako čestné vyznamenání. Někteř́i informanti ve Vietnamu i v České republice se ovšem domnívají, že se k tomuto příjmení mnoho aktérů přihlásilo právě proto, aby mohly být jejich rodiny spojovány se zmíněným vládnoucím rodem.

Př́ijmení se ve vietnamských rodinách předává v patrilineární linii a na děti tak automaticky přechází rodové jméno jejich otce. Zajímavé je, že v rámci uzavření manželství toto př́ijmení nepřijímá po svém manželovi i manželka, ta si naopak ponechává své rodné př́ijmení po celý svưj život.

„Táta je Lê a máma Trân a vím, že takový to smýšlení jakože rodiče mají jiný př́imení, tak musí být rozvedený nebo se nevzali a tak, to mi trošku vadilo dŕív, aby si někdo nemyslel, že mám rozvedený rodiče nebo, že se nevzali. Ted' to neřeším, nebo se o tom možná víc ví, že si vietnamská žena nebere př́ijmení svého muže." (Honza, 22 let) 
Pokud se vrátíme k výše zmíněným ženským a mužským jménům $\mathrm{z}$ předchozí části textu a budeme o jednotlivých dvojicích hovořit jako o manželích - označíme je za manžele Quốc Anh Tuyết nebo Dược Thịn Hường - oslovováni jsou nikoliv podle příjmení muže, nýbrž podle spojení manželova a manželčina křestního jména. Vysvětlení můžeme $\mathrm{v}$ tomto vidět hned třikrát. Za prvé užívaných vietnamských př́ímení není $\mathrm{v}$ oběhu př́liš mnoho a bylo by tak velmi těžké rozpoznat, o kterou rodinu se jedná, pokud bychom je označili pouze například za Nguyễnovi bez dalšího upřesnění. Spojení křestních jmen ovšem skýtá pravděpodobně nejoriginálnější a nejméně zaměnitelné označení. Za druhé jsou $\mathrm{z}$ historického hlediska přímení pro vietnamskou společnost stále spíše novinkou a je pravděpodobné, že toto označování přetrvává z minulosti. A za třetí můžeme říci, že manželé nemohou být označováni společným př́imením, jelikož manželka není nositelkou stejného označení rodu jako manžel. Příjmení tak na rozdíl od západoevropského prostředí ${ }^{7}$ netvoří rámec pro sociální vztahy a individuální zařazení jedince, které dává aktérovi právě jeho křestní jméno.

Podobným způsobem funguje i spojení křestních jmen, které velmi často odlišují nejen jedince $\mathrm{v}$ rámci společnosti, ale také $\mathrm{v}$ rámci rodiny. Vietnamci $\mathrm{k}$ oslovení běžně používají dvě kř̌estní jména, což pomáhá $\mathrm{k}$ identifikaci konkrétního jedince ve chvíli, kdy se některá jednotlivá křestní jména a př́ijmení velmi často opakují. Př́ikladem mohou být dvě ženy s prŕjmením Trần - Lan Anh a Thanh Anh - obě mají stejná koncová křestní jména a odlišuje je tedy prostřední jméno.

Jednou z mála oficiálních modifikací, $\mathrm{k}$ níž dochází v rámci ženského př́ijmení vietnamských žen v České republice, je přidání příčestí „-ová“ po získání českého občanství. Tato specifická koncovka se stává i jednou z genderových odlišností ve vietnamském jméně, která je poté např́íklad pro Čecha patrná na první pohled. Dokonce díky tomu působí př́ijmení i jeho nositelka mnohem méně cizokrajně.

„Jak jsem získala české občanství, tak mám v dokladech Leová a najednou se cítím být jako Češka. U mě osobně se mi to líbí, asi nevím, jakože, když se představím a zvedám telefon a říkám Leová, tak mám takový pocit, jakoby krok bliž k tomu, aby mě mín diskriminovali, aby moje jméno neznělo tak cize, když tam mam Leová, tak to jakoby zní trochu víc jako bych byla Češka" (Linda, 25 let)

\section{PŘEZDÍVKY JAKO NEOFICIÁLNÍ JMÉNA}

Definujeme-li přezdívky jako „neúřední, doplňkové vlastní jméno, které většinou charakterizuje osoby, místa nebo věci a vztahuje se k povolání, vlastnostem, původu atd. nositele jména“ (Pleskalová - Karlík - Nekula 2002, 354), jedná se

7 Pro západoevropské prostředí je typické, že právě př́immení nás zařazuje do konkrétní sociální struktury, jak popisuje na př́kladu bulharských Čechů L. Budilová (2012a).

\begin{tabular}{|c|c|c|c|}
\hline Pohlaví & Jméno & Přezdívka & Typ přezdívky \\
\hline $\mathrm{M}$ & Phuoc & Lucky & překlad do AJ \\
\hline$\check{Z}$ & Kim Ngan & Kim & modifikace \\
\hline $\mathrm{M}$ & Vo & Joe & angl. jméno \\
\hline$\check{Z}$ & Pham & Pam & angl. jméno \\
\hline $\mathrm{M}$ & Phů & Tom & angl. jméno \\
\hline$\check{\mathrm{Z}}$ & Linh & Linda & české jméno \\
\hline$\check{Z}$ & Hanh & Hana & české jméno \\
\hline$\check{Z}$ & Anh & Anne & angl. jméno \\
\hline $\mathrm{M}$ & Te Ding & Tedy & modifikace \\
\hline $\mathrm{M}$ & Quang & Honza & české jméno \\
\hline$\check{\mathrm{Z}}$ & Hoang & Jana & české jméno \\
\hline $\mathrm{M}$ & Thinh & Tomáš & české jméno \\
\hline$\check{\mathrm{Z}}$ & Yen & Jane & angl. jméno \\
\hline
\end{tabular}

Tabulka 1. Vybrané př́ílady jmen a přezdívek. Legenda: M- muž, Ž - žena, AJ - anglický jazyk

tak o neoficiální/neúřední jména, která jedinec použivá bud' z vlastní vůle, nebo díky vlivu společnosti. Toto neoficiální jméno získává až v průběhu života podle vlastností či okolností, v nichž se nachází (Svoboda 1964, 41). S přezdívkou může být díky tomu nakládáno jako $s$ referenčním nástrojem, který společnost používá k odkázání na konkrétní osobu (Budilová 2012b, 7-8) nebo ji můžeme uchopit jako takzvaně adresnou, jíž nositelé chtějí být sami oslovováni a mnohdy si ji i dokonce sami zvolí.

Rozlišit můžeme několik motivů vzniku přezdívek, některým bude věnována pozornost $\mathrm{v}$ následujícím textu - kromě toho jsou ale přezdívky i reakcí na soudobou společenskou situaci a sociální vztahy (Knappová 1999, 82). „Tvorba přezdívek je tedy pojmenovávacím procesem přinášejícím stále svěží materiál, takže přezdívky se tak zároveň stávají výmluvnými svědky dobové společenské situace i mezilidských vztahü“ (Knappová 1999, 86). Přezdívky a neoficiální anglická či česká jména by měly být považovány za reakci na současnou situaci, v níž se nacházejí vietnamští migranti či jiní Vietnamci, kteří se často stýkají s cizinci a ne-vietnamsky hovořící populací. Nejedná se tím pádem o přezdívky, které by vznikaly uvnitř určité skupiny, např́klad o přezdívky Vietnamců mezi Vietnamci, ale o pseudonymy, které se vytvářejí skrze kontakt $\mathrm{s}$ jinou skupinou. Právě z tohoto hlediska je v práci pohlíženo na česká/anglická jména a další přezdívky Vietnamců, kteří i přesto, že mají v rodném listě Nguyễn Quangh Son se představují jako Tomáš. Tato neoficiální jména/přezdívky jsou utvářeny třemi způsoby - jedná se bud' o neoficiálně přijatá česká či anglická jména, modifikace oficiálních vietnamských jmen nebo jejich překlady. ${ }^{8}$

8 Viz Tabulka vybraných př́íkladů jmen a přezdívek některých aktérů výzkumu. 
Jedním z nejčastějších typů přezdívek u Vietnamců je přezdívka motivovaná rodným jménem nositele (Knappová 1999, 87) - ty vznikají bud' rýmováním, nebo přetvořením hláskového skladu: Hanh - Hanna; asociací: Linh - Linda; zkratkováním přezdívek: Te Ding - Tedy. Ve Vietnamu se pak častěji než v Čechách objevují přezdívky jmen vzniklé překladem (Knappová 1999, 88), viz prríklad Phuoc - Lucky.

Česká jména nejčastěji získala většina informantů v době raného dětství od českých chův/tet ${ }^{9}$ nebo $\mathrm{v}$ mateřské škole. Důvod byl prostý, většina Čechů nedokázala oficiální vietnamské jméno ani přečíst, takže volili první nejjednodušší cestu a to volbu české přezdívky. Ty byly vytvořeny bud' na základě podobnosti s oficiálním vietnamským jménem (př. Hanh - Hanka) nebo náhodně podle oblíbenosti českých jmen. Prakticky každý český Vietnamec má své české jméno mnohdy i ve starší generaci - nutností je zejména u těch, kteří se pravidelně setkávají a komunikují na osobní bázi s majoritní společností.

„Když se někdo jmenuje třeba Tam, tak se mu říká Tomáš jako $T$ a T,. ale druhej brácha, ten se jmenuje Vu a podle toho V tak jsem ríkal, že se mi líbí třeba Viktor, ale tenkrát s tím jako nesouhlasili, jako že by se mu říkalo Viki a že to zní prostě jako zženštile a tak nakonec někdo přišel s tím, že Pavel je hezký jméno a říká se mu Pája. " (Tomáš, 22 let)

„To jméno mi dala vlastně chưva, protože nevěděla, jak mi ř́kat česky. Tak mi dala to jméno Filip, takže mi tak ř́kali jako od mateřský na základce a prostě na gymplu. " (Filip, 27 let)

Zajímavé je, že zvolená jména bývají jedněmi z nejčastějších, které jsou $\mathrm{v}$ dané společnosti užívány. $\mathrm{Z}$ anglických jmen se často vyskytuje Joe u českých pak Pavel, Tomáš, z ženských Lenka či Hana.

„Lenka a Hanka se dává často, já myslim, že je to proto, že je to nejčastější jméno, co se dá rychle vyslovit. Vybrala mi to učitelka ve školce" (Lenka, 24 let)

Ve Vietnamu se naopak zdá, že si anglická jména či přezdívky jedinec velice často volí spíše sám v období dospívání. V dětství se vietnamské děti tak často s cizinci nesetkávají a neexistuje zde tak žádná potřeba modifikace jména. Na druhou stranu v dospělosti už se s těmito situacemi vyrovnávají právě tvorbou přezdívek - velice často si např́íklad průvodci turistů začnou ř́kat anglickým jménem.

K modifikaci oficiálního jména na přezdívku dochází oboustranně bud' komolením oficiálního jména, na nějž adresát přistoupí nebo jeho představením už modifikovaným jménem - přezdívkou. Stejně tak překlad jména je záměrným vytvořením přezdívky a obojí se dá pokládat za určitou taktiku užíání jiného než oficiálního jména jedince.

9 Fenoménu českých chův a tet pro vietnamské děti se ve své práci věnuje Souralová $(2012,2013)$

\section{JMÉNO JAKO TAKTIKA}

Výše popsané zacházení se jménem a přezdívkou, jejich vytváření a referenční či adresný rámec se dá označit za klasifikační a identifikační prvek pojmenovávání. Jak ovšem bylo naznačeno $\mathrm{v}$ úvodu práce - jméno samotné může být použito i jako přístupové heslo do určité skupiny či společnosti (Bankova 2008) a jedinec ho může během života modifikovat a využívat i jako určitou strategii. Oslovení, které si jedinec vybírá nebo je mu zvoleno, nabízí pohled na to, jak bude jeho nositel vnímán, do jaké společnosti bude zařazen, dotvář́ tak část jeho identity a postavení (Aceto 2002, 577-578).

První taktika, která ve spojení s modifikací jména přezdívkami byla $\mathrm{v}$ rámci výzkumu identifikována, je potřeba zjednodušení jména. Druhá, jenž na ní svým způsobem navazuje je schopnost jméno využívat podle skupiny, se kterou se informanti setkávají nebo s níž chtějí být ztotožňováni.

Vietnamština, jak již bylo poukázáno, má šest tónů a vyslovovat jméno správně je pro jedince, který jí neovládá, velmi obtížné. Navíc je k oslovení jedince také často použito spojení dvou křestních jmen (př. Lan Anh, Kim Ngan). Pro zjednodušení komunikace a oslovování informanti svá jména často modifikují, zkracují, přetrpí špatnou výslovnost či si ponechají neoficiální jména v anglickém a českém jazyce.

Ve Vietnamu umožňuje představení sama sebe anglickým jménem či přezdívkou (viz příklad jména Lucky) snazší komunikaci s cizinci, zejména turisty, kteří do země přicházejí. Všichni informanti se vzdělávají v angličtině a věří, že jednou budou pracovat pro zahraniční společnosti, vycestují či budou alespoň cizince ve své zemi potkávat. Zároveň ví, že jejich jména jsou pro tyto jedince obtížná. Navíc představení se rovnou anglickým jménem tvoří v západních turistech pocit zvláštní sounáležitosti a boří bariéry, které často přináší problém výslovnosti jména. Zároveň se to pro mnoho mladých Vietnamců stává zajímavým otvíracím vtipem pro navázání přátelské konverzace a odlehčení atmosféry.

„No jasně, že mi můžeš ř́kat jen Kim“ (Kim, 20 let)

"Jsem Te Ding - ale ř́ikej mi Tedy, to pro tebe bude jednodušši“ (Tedy, 22 let)

Zatímco ve Vietnamu je přezdívka, která se užívá pro komunikaci s cizinci spíše volbou v průběhu života, která navazuje na konkrétní situaci, práci či osobu, s níž jedinec jedná, v Čechách získávají mladí Vietnamci svá česká jména v útlém dětství a nemohou do nich zasahovat - ne vždy jsou s nimi spokojeni a smířeni. Důvod jejich užívání je ale prakticky stejný jako ve Vietnamu - potřeba zlepšení komunikace, zjednodušení života, přiblížení se majoritní české společnosti.

„Ty český se dávají, aby se to dítě mohlo líp integrovat do český skupiny dětí. Nad to, že vypadá jinak, aby ještě nemělo hrozně cizí a zvláštní jméno a ty menši dèti si $z$ něho neutahovali. “ (Vojta, 24 let)

To má ovšem i opačný vliv na jedince často svázaný s identi- 
tou a pocitem sounáležitosti $\mathrm{k}$ vlastní skupině. Zatímco české jméno je využíváno $\mathrm{v}$ komunikaci s českým prostředím: mateřská škola, základní škola, české chůvy, kamarádi, vietnamské jméno je spojeno s rodinným zázemím, vietnamskou komunitou, práteli a rodinou ve Vietnamu. Častým jevem se tak stává, že pokud mladí Vietnamci v České republice komunikují v češtině, používají mezi sebou česká jména. Naopak ve chvíli, kdy hovoří ve vietnamštině, použijí vietnamské jméno. Tato situace je ještě více viditelná v rodinném prostředí, a to např́klad mezi sourozenci.

„Když si povídáme česky, tak se řekne Terka a ve vietnamštině používáme vietnamský jméno. My jsme jí (pozn. sestře informantky) od malička říkali, že to má říkat takhle, aby zároveñ dodržovala pravidla oslovování a oslovoval mě ještě před jménem 'chi'“"(Terka, 21 let)

Zajímavým fenoménem u informantů v České republice je rozhodnutí přestat $\mathrm{v}$ období dospívání používat českou přezdívku. Důvodem často bývá uvědomění si, že chtějí být oslovováni vlastním oficiálním jménem, že chtějí být identifikováni jako Vietnamci. Důležité je zde zmínit, že se v tomto směru často nejedná pouze o užívání jména, ale i obnovení zájmu o vietnamštinu a rodinné obyčeje.

„Když jsem měla možnost to nějak změnit, tak jsem si řekla, že se nebudu představovat Linda... ̌̌e se budu predstavovat Linh, že se to dobře vyslovuje a že je to prostě moje jméno. tak si tak budu řikat." (Linda, 25 let)

„Já si myslim, že si to dítě tak jako uvědomí, že není jen Čech, že je $i$ Vietnamec, že třeba to jméno není tak špatný nebo se nevyslovuje tak zle, že by asi nechtělo, aby mu lidi říkali ve 40 Jana, že chtějí, aby používali ostatní pravé jméno. "(Tomáš, 22 let)

Př́kladem podobné situace je i užití jména na sociálních sítích, kdy zejména po překročení náctiletého věku většina Vietnamců v České republice používá svá oficiální celá vietnamská jména. To odkazuje zejména na vlastní vědomí symbolického spojení jména s Vietnamem a př́buznými, se kterými skrze sociální sítě a internet udržují vztah mnohdy i na dálku.

„Většinou máme všichni český jména, ale vím, že kolem věku maturity nebo na střední si třeba mění i jména na FB, že před tím tam mèli, já nevim: Jana Tran Thi.. bla bla... tak si to změní a maj tam jen vietnamské jméno." (Maja, 26 let)

„Že často třeba v pubertě to mají na FB a predstavují se a říkají si českým jménem, ale pak nějak po pubertě a tak si ř́kají třeba víc vietnamským jménem a smažou si to český jméno, už se představujou jen tím svým vietnamským jménem" (Ondra, 24 let)

„To jsem si všimla, že spousta mých přátel si smazalo ty český jména a pritom každý tam před tím měl to svoje vietnamské jméno a potom i to český" (Linda, 25 let)

Stejně jako anglické jméno spojuje informanty ve Vietnamu s turisty a cizinci celkově, české jméno umožňuje vietnamským migrantům snazší fungování v majoritní společnosti, oficiální vietnamské jméno se stává pojítkem s vietnamskou kulturou, rodinou a tradicí. Za prvé v tomto můžeme spatrovat hodnotu jména jako vstupního údaje do určité společnosti. Za druhé zde nalézáme prvky vyjádření etnicity jakožto náležitosti $\mathrm{k}$ určité skupině v rámci dané situace a relace (Eriksen 2007, Barth 1969). Tento typ přezdívek může být označen také jako etnické jméno (Aceto 2002), kterým se jedinec přibližuje k určité společnosti, vyjadřuje k ní solidaritu a soudržnost. Používáno je tím pádem jen $\mathrm{v}$ daném socio-kulturním prostředí, do kterého náleží. $\mathrm{V}$ případě, že migranti zvolí již po narození běžné jméno $\mathrm{z}$ majoritní společnosti jako oficiální úřrední jméno, je to dokonce výrazem akulturace a dle výzkumů má tak jedinec umožněno snazší působení v hostitelské zemi, což se projevuje naprríklad v navazování osobních a pracovních vztahů (Gerhard - Silke 2009). Užívání přezdívek, pseudonymů, dávání oficiálních jmen z řad majoritní společnosti je taktikou nejen Vietnamců v Čechách, ale i migrantů a cizinců v jiných zemích. Popsány jsou podobné př́ípady např́klad $\mathrm{u}$ Turků a migrantů $\mathrm{z}$ bývalé Jugoslávie v současném Německu (Gerhard - Silke 2009), afro-panamských obyvatel ostrova Bastimentos (Aceto 2002) či Korejců v Torontu (Kim 2007). Tato pojmenování souvisí se zařazením a fungováním jedince $\mathrm{v}$ určité skupině, prostupují hranice mezi majoritní a minoritní společností či odkazují k etnické identitě.

\section{ZÁVĚR}

Na prŕkladu mladých Vietnamců v Čechách i ve Vietnamu byly nastíněny praktiky a taktiky zacházení se jmény a přezdívkami. Vietnamci jako migranti přicházeli do Československé socialistické republiky od padesátých let minulého století a od roku 1989 do dnes vzrostl jejich počet zhruba na 60000 osob. Naopak do Vietnamu začalo v druhé polovině 20 . století proudit více a více turistů, anglicky mluvících jedinců, kteří ovlivňují zejména život ve velkých městech a turistických zónách. Právě střetávání různých společností a jazyků zapříčinilo potřebu tvorby specifických přezdívek a modifikaci oficiálních jmen, které zjednodušují vzájemnou komunikaci. Cílem studie bylo poukázat na podobnosti a odlišnosti mezi vietnamskou komunitou v českém prostředí i ve Vietnamu, které se v oblasti pojmenovávání a tvorby přezdívek objevují. Zároveň byla jedna $\mathrm{z}$ částí práce věnována $\mathrm{i}$ samotnému pojmenovávání vietnamských dětí a užívání př́ijmení, jelikož právě oficiální vietnamská jména tvoří z velké části prostor pro tvorbu pseudonymů.

Informanty se stali v Čechách i ve Vietnamu mladí lidé ve věku dvaceti až třiceti let, kteří mají zkušenost s dlouhodobým životem v majoritní české společnosti nebo se pravidelně stýkají $\mathrm{s}$ cizinci. Za jeden $\mathrm{z}$ hlavních hybatelů u modifikace vietnamských jmen a vytváření přezdívek můžeme považovat obtížnou výslovnost pro cizince. Dalším bodem je přizpůsobení se společnosti, se kterou kooperují, at’ už se jedná o formu „české/anglické přezdívky“, počeštělé př́ijmení nebo tolerování 
špatné výslovnosti. Zobecněně můžeme trochu troufale říci, že jména nejsou jen nositelem naší identity, ale zároveň nám umožňují pohybovat se v určité společnosti. Správně zvolené jméno nebo pseudonym může usnadňovat komunikaci mezi jedinci, otevírat pomyslné dveře do jiné skupiny a právě pro tyto účely není pro nás mnohdy problém ho změnit.

\section{LITERATURA}

Aceto, Michael (2002): Ethnic personal names and multiple identities in Anglophone. Language in Society, 31, 577-608.

Alves, Mark (2009). Sino-Vietnamese Grammatical Vocabulary And Sociolinguistic Conditions For Borrowing. Journal of the Southeast Asian Linguistics Society, 1, 1-9.

Bankova, Petia (2008): The Given Name - Sign of Identifi cation. In: Marushiakova, Elena, ed., Dynamics of National Identity and Transnational Identities in the Process of European Integration. Cambridge Scholars Publishing, 130-137.

Barth, Fredrik (1969): Ethnic Groups and Boundaries: The Social Organization of Culture Differences. Boston: Little, Brown.

Berg, Bruce L. (2001): Qualitative research methods for the social sciences. USA: Allyn \& Bacon.

Bernard, Russell H. (1995): Research methods in anthropology, qualitative and quantitative approaches. USA: Altamirra.

Bernard, Russell H. (2006): Research methods in anthropology, qualitative and quantitative approaches. USA: Altamirra.

Brouček, Stanislav (2003): Aktuální problémy a adaptace vietnamského etnika $v \check{C} R$. Praha: Etnologický ústav AVČR.

Budilová, Lenka (2012a): „At’ se neztratí jméno.“ Jména a pojmenovávání u bulharských Čechů, Český lid, 99(4), 407-425.

Budilová, Lenka (2012b): Původ, význam a používání přezdívek u bulharských Čechů, Antropologia Integra, 3(1), 1-9.

Cooke, Thomas J. (2008): Migration in a family way. Population, space and place, 14, 255-265.

Černík, Jan (2006): Vietnamští žáci na základních školách: náčrt problémů a přístupů. In: Černík Jan a kol., eds., S vietnamskými dětmi na českých školách. Jinočany: H\&H, 169-177.

Dang, Nghien Van - Chu Thai Son - Luu Hung (2000): Ethnic Minorities in Vietnam. Hanoi: The Gio.

Buss, Claude (1958): Southeast Asia and the World Today. USA: D. Van nostrand Company.

Eriksen, Thomas H. (2007): Antropologie multikulturních společností: rozumět identitě. Praha: Triton.

Evergeti, Venetia - Ryan, Louise (2011): Negotiating transnational caring practices among migrant families. In: Kraler Alebert a kol., eds., Gender, generation and the family in international migration. Amsterdam: Amsterdam university, 355-373.

Finch, Janet (2008): Naming Names: Kinship, Individuality and personal names. Sociology, 42, 709-725.

Freidingerová, Tereza (2014): Vietnamci v Česku a ve světě: migrační a adaptační tendence. Praha: Slon.

Geertz, Hildred - Geertz, Clifford (1964): Teknonymy in Bali: Parenthood, age-grading and genealogical amnesia. Journal of the Royal Anthropological Institute, 94, 94-108.

Gerhards, Jürgen - Silke Hans (2009): From Hasan to Herbert: Name-Giving Patterns of Immigrant Parents between Acculturation and Ethnic Maintenance. American Journal of Sociology, 114(4),1102-1128

Hammersley,Martyn-Atkinson,Paul(1997).Ethnography:PrinciplesinPractice. London: Routledge.

Hendl, Jan (2005): Kvalitativní výzkum, základní metody a aplikace. Praha: Portál.

Kim, Tae-Young (2007): The dynamics of ethnic name maintenance and change: Cases of Korean ESL immigrants in Toronto. Journal of multingual and Multicultural development, 28(2), 117-133.

Kirkpatrick, Andy (2010): English as a lingua franca in ASEAN: A multilingual model. Hong Kong: Hong Kong University Press.

Knappová, Miloslava (1999): Přezdívky v proměnách staletí. Acta onomastica, 40, 82-88.

Kocourek, Jiří (2006): Vietnamci v ČR. In: Leotiyeva Yana, ed., Menšinová problematika $v$ ČR: Komunitní život a reprezentace kolektivních zájmů (Slováci, Ukrajinci, Vietnamci, Romové). Sociologický ústav Akademie Věd ČR: Praha, 46-62.

Lê, Trung Hoa (2005): Họ và tên người Việt Nam. Hà Nội, Việt Nam: NXB Khoa học Xã họi.

Lévi-Strauss, Claude (1996): Myšlení přírodních národů. Praha: Dauphin.

Martínková, Šárka (2008): Sociabilita vietnamského etnika v Praze. In: Uherek Zdeněk a kol eds., Cizinecké komunity z antropologické perspektivy: Vybrané př́pady významných imigračních skupin v České republice. Praha: Etnologický ústav AVČR, 167-210.

Martínková, Šárka (2010): Vietnamská komunita v Praze. Praha: Muzeum hlavního města Prahy.

Nguyên, Thê Anh (1985): The Vietnamese Monarchy under French Colonial Rule 1884-1945, Modern Asian Studies, 19(1), 147-162.

Nguyễn, Van Hue a kol. (2013): : Giáo trình tiếng Việt cho người Hàn Quốc Nước Ngoài: Vietnamese as a second langure. Nhà Xuất Bản Đại Học Quốc Gia: Ho Chi Minh City.

Pechová, Eva (2007): Migrace $z$ Vietnamu do České republiky v kontextu problematiky obchodu s lidmi a vykořistováním. Praha: La Strada Česká republika, o. p.s.

Pleskalová, Jana - Karlík, Petr - Nekula, Marek (2002): Encyklopedický slovník češtiny. Praha: Nakladatelství Lidové noviny.

Sataryová, Kristýna (2014): Percepce domova u potomků vietnamských migrantů. Kulturní studia, 1, 80-100.

Shakespeare, William (2011): Romeo a Julie. (online). http://web2.mlp.cz.

Souralová, Adéla (2013): She gave us family life: Vietnamese immigrante families and their czech nannies redefining relatedness. Urban People, 15(2), 257-278.

Souralová, Adéla (2012): Vietnamské rodiny a jejich české chůvy: Vzájemná závislost a péče o děti. Sociální studie, 3, 31-50.

Spradley, James P. (1980): Participant Observation. Wadsworth: Cengage Learning.

Svoboda, Jan (1964): Staročeská osobní jména a naše přijmení. Praha: Nakladatelství československé akademie věd.

Toušek, Ladislav (2012): Vybrané aspekty metodologie aplikované antropologie. In: Hirt Tomáš a kol., eds., Vybrané kapitoly z aplikované sociální antropologie. Plzeň: ZČU, 25-106.

vom Bruck, Gabriele - Bodenhorn, Barbara (2006): "Entangled in histories": An Introduction to the Anthropology of Names and Naming. In: vom Bruck, Gabriele - Bodenhorn, Barbara, eds., The Anthropology of Names and Naming. Cambridge University Press, 1-30.

\section{AUTORKA}

Lenka Bednárová je studentkou doktorského oboru Etnologie na Filozofické fakultě ZČU. Od magisterských studií se věnuje tématům antropologie sexuality, genderu a rodiny. Zároveň díky výzkumu $\mathrm{k}$ disertační práci, který tematicky pojednává o první a půlté a druhé generaci Vietnamců v Čechách - zejména vnímání genderu a rodiny, získala možnost nahlédnout do „světa“ této komunity v Čechách. A nejen to, zájem o cílovou skupinu jí zavedl i na několik měsíců na univerzitu v Ho Chi Minh City, kde se věnovala studiu vietnamštiny. V současné době dokončuje disertační projekt, prohlubuje znalosti jazyka a chystá se na další cestu do „Indočíny“. 